\title{
THE USE OF THE PURE VERATRUM ALKALOIDS NEOGERMITRINE AND PROTOVERATRINE IN HYPERTENSION
}

\author{
BY \\ A. E. DOYLE AND F. H. SMIRK \\ From the Department of Medicine, Otago University Medical School, Dunedin, New Zealand
}

Received November 20, 1952

The veratrum alkaloids were used clinically prior to the detailed knowledge of their pharmacology, Baker (1860) describing the successful treatment of a case of eclampsia. The pharmacological actions of the alkaloids were reported by Prevost in 1866, and von Bezold and Hirt (1867) attributed the fall in blood pressure and bradycardia to vagal reflexes arising from the heart itself. Cramer (1915) thought these actions were due to a vagal reflex from the lungs.

The pure alkaloid protoveratrine, derived from veratrum album, was studied by Krayer et al. $(1944,1946)$, renewing clinical interest in the veratrum alkaloids. They reported that the hypotensive effect was due to the presence of ester alkaloids like protoveratrine. They confirmed the work of von Bezold, reporting that the afferent impulses producing the reflex fall in blood pressure arose mainly in the heart, and agreed with Cramer that some afferent impulses were derived from the lungs and suggested that the "carotid sinus area" was concerned, the latter suggestion being supported by the observations of Aviado et al. (1949).

Freis et al. (1949), in an investigation of the hæmodynamic effects of the veratrum alkaloids (vertavis and veratrone) in man, reported that the hypotensive effect was due to a decrease in peripheral resistance in the limbs and splanchnic areas without any fall in cardiac output. The decrease in peripheral resistance was apparently caused through the sympathetic nervous system as the drugs did not increase the peripheral blood flow in sympathectomized limbs, whereas they did so in normally innervated limbs. They found that the alkaloids were not sympatholytic, for pressor reflexes were maintained and postural hypotensios did not occur.

Authors using various preparations of mixed veratrum alkaloids in the treatment of hypertension are in agreement that in some patients toxic reactions prevent the administration of effective hypotensive doses. Some authors (Hite, 1946; Freis and Stanton, 1948; Faust, 1951) found these patients to be in a minority, while others (Coe et al., 1950; McNair et al., 1950; Kauntze and Trounce, 1951; Barrow and Sikes, 1951: Smirk and Chapman, 1952) thought they were in a majority. There is general recognition, however, that these alkaloids, were it not for the frequency with which toxic side effects occur, would be suitable therapeutic agents in the treatment of hypertension, since they do not impair sympathetic reflexes or cause marked postural hypertension except in toxic doses. Furthermore, they are effective by mouth, and the effect of a single dose is maintained for several hours; the wide variations in arterial levels that may be produced by ganglion blocking agents such as the methonium compounds are thus avoided.

Some clinical observations have been made also with pure veratrum alkaloids. Meilman and Krayer (1950), in a study of the action of protoveratrine given intravenously in man, found that a significant fall of blood pressure could be produced without serious complications.

In 1950, Freis et al. reported the use of two previously undescribed crystalline alkaloids of veratrum viride, germitrine and germidine, both of which exhibited strong hypotensive activity in 
man when given orally or intravenously. They concluded that the toxic effects of extracts of veratrum viride were not derived entirely from contaminating constituents in the drug, since similar reactions followed administration of the pure crystalline alkaloids.

Our objects are (1) to examine the effects of oral veratrum therapy in hypertensive patients, using the pure alkaloids neogermitrine and protoveratrine, and various alkaloidal mixtures such as anatensol, vertavis, and a mixed alkaloid preparation from Messrs. S. B. Pennick \& Company, and (2) to compare the effects of neogermitrine and protoveratrine given by mouth and by injection, with particular reference to toxic manifestations. The observations have been made on 65 patients suffering from hypertension of varying ætiology, mostly essential hypertension.

\section{Materials AND Methods}

Using the general method described by Fried et al. $(1949,1950)$, a supply of the pure alkaloids of veratrum viride was prepared by Mr. W. G. H. Edwards of the Chemistry Department, University of Otago, to whom we are indebted for the following summary of the method of extraction.

A total of $40 \mathrm{lb}$. of the dried roots was extracted in two batches with benzene (33 gallons) and 0.880 ammonia (1 $1 \frac{1}{2}$ litres) until the concentration of solid in the extract fell to $0.1 \mathrm{~g}$./litre. Evaporation in vacuo was effected in a 10-gallon still and was carried to a volume of $2 \frac{1}{2}$ litres.

The further extraction of this was carried out according to the paper quoted above, giving the following fractions :

(a) a jervine-veratramine fraction (about $50 \mathrm{~g}$.),

(b) a rubijervine-isorubijervine fraction (7.0 g.),

(c) secondary bases-isolated as acetyl derivatives, and

(d) 3-4 g. of biologically active material, which on assay in the hypertensive patient was active in doses of $1-2 \mathrm{mg}$.

Fraction $(d)$ was submitted to 24 cell Craig distribution between benzene and 2-molar acetate buffer of $p \mathrm{H} \mathrm{5.5}$. This distribution did not parallel that of the American workers, since only one more fraction appeared to be obtained, together with two smaller fractions and two intermediate ones. These are related as below.

$\begin{array}{lll}\text { Fraction I } & 0.6 \mathrm{~g} . & \text { Cells 2-8 inclusive } \\ \text { Fraction II } & 1.6 \mathrm{~g} . & \text { Cells 9-14 inclusive } \\ \text { Fraction III } & 2.25 \mathrm{~g} . & \text { Cells 15-17 inclusive (Intermediate fraction) } \\ \text { Fraction IV } & 0.45 \mathrm{~g} . & \text { Cells 18-21 inclusive } \\ \text { Fraction V } & 0.17 \mathrm{~g} . & \text { Cells 22-23 inclusive (Intermediate fraction) }\end{array}$

Fraction II was found in biological assay to have about five times the activity of germidine, and chemical studies of this fraction by Mr. Edwards of the Otago University and by Dr. Wintersteiner of the Squibb Institute for Medical Research showed it to be neogermitrine.

\section{SELECTION OF CASES}

The patients in whom the trials were made had been referred to the clinic because of bigh casual blood pressure readings and in the majority of them symptoms of hypertension were present. In most patients the basal blood pressures (Smirk, 1944; Kilpatrick, 1948) were also considerably raised. Patients who exhibited labile hypertension, with high casual blood pressures but much lower basal blood pressures, were not excluded from the trials, as many had had hypertensive symptoms for some time, and most had supporting radiological or electrocardiographic evidence of left ventricular hypertrophy. In some patients with low basal blood pressures who apparently responded well to veratrum therapy, a trial with an inert substance was made.

Blood pressures were recorded in accordance with recommendations of the Committee for the Standardization of Blood Pressure Readings of the American Heart Association and of the Cardiac Society of Great Britain and Ireland (1939).

The case numbers used correspond with those in earlier publications (Smirk and Alstad, 1951; Smirk and Chapman, 1952). 
Intravenous Administration. The patients were lying in a quiet room. Several estimations of the blood pressure were made over a preliminary period of about 10 minutes. Tuberculin syringes were mounted in a micrometer device (Fig. 1), such that one complete turn of a screw delivered $0.2 \mathrm{ml}$. (0.04 mg.) of a solution of 0.02 per cent neogermitrine in 0.1 per cent acetic acid. The syringe was connected to the intravenous needle by a length of rubber pressure tubing with a

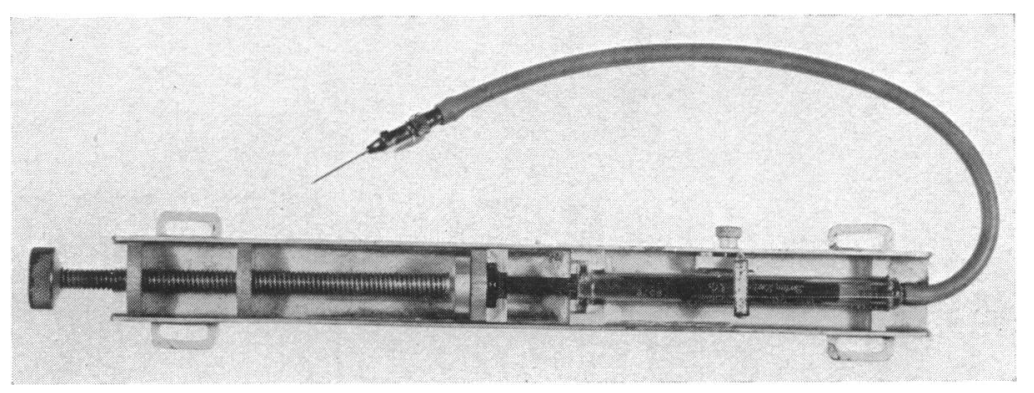

FIG. 1.-Micrometer syringe emptying device.

capillary bore. Small intravenous injections of neogermitrine were administered at two-minute intervals with estimation of the blood pressure and pulse rate. When the blood pressure had fallen to near normal or to hypotensive levels, or if toxic symptoms appeared, the needle was withdrawn. Blood pressures and pulse rates were then measured in the recumbent and erect postures until the readings had reached their previous level.

Oral Trials. After preliminary recordings of the blood pressure and pulse rates the veratrum preparation to be tested was given-usually fasting, but on occasion after food. Blood pressure and pulse rates were recorded with the patient in the sitting and erect postures at half-hourly intervals, and the onset and duration of any toxic manifestations were recorded.

Where a good fall of blood pressure could be obtained without appreciable toxic effect the patient was subsequently treated as an out-patient with either a mixed or a pure alkaloidal preparation. Symptomatic relief without effective blood pressure control has not been the aim of the present investigation.

\section{RESULTS}

Administration of Inert Control Substances. Eleven patients received either diluted Tr. capsicum by mouth or an injection of sterile normal saline solution. The patients were unaware of the substitution, and the blood pressures were recorded in the usual manner. In eight patients, falls in the systolic level of more than $30 \mathrm{~mm}$. Hg occurred after the administration of one or other of these substances. A typical example was Case 268, in whom the resting minimum blood pressure was $198 / 128$, readings of $168 / 110$ being noted $1 \frac{1}{2}$ hours after the injection of $1 \mathrm{ml}$. of normal saline. Hence, we have disregarded falls in blood pressure of under $40 / 20 \mathrm{~mm}$. $\mathrm{Hg}$ as being possibly due to spontaneous variation. A fall in blood pressure of this order was obtained in many patients taking veratrum alkaloids without significant toxic effects, but we feel that many of these falls in blood pressure are due to a placebo action and are not related to the specific effect of the drug administered. It may be assumed in the clinical trials that follow that only blood pressure falls which exceed 40/20 are regarded as likely to be due to the specific action of the veratrum alkaloids.

Parenteral Administration of Pure Veratrum Alkaloids. (A) Intravenous Neogermitrine. Twentyone patients were given neogermitrine intravenously. The initial dose was usually $0.04 \mathrm{mg}$. Injections of $0.02 \mathrm{mg}$. at two-minute intervals were then given until the blood pressure began to fall. The dose was then further reduced to 0.01 or $0.005 \mathrm{mg}$. at two-minute intervals until the blood pressure had reached a systolic level of about 120 to $130 \mathrm{~mm}$. $\mathrm{Hg}$, or until toxic manifestations had 
occurred. The needle was then withdrawn. The total dose given ranged from $0.09 \mathrm{mg}$. to 0.42 $\mathrm{mg}$., and the time taken for these doses to be administered was 8 to 30 minutes. The blood pressure and the pulse rate usually fell by stages as more drug was given (Fig. 2), but in some patients no effect was observed until a critical level was reached, very small doses then producing a large fall. The precipitous fall of blood pressure occurring when a critical dose is attained and after the

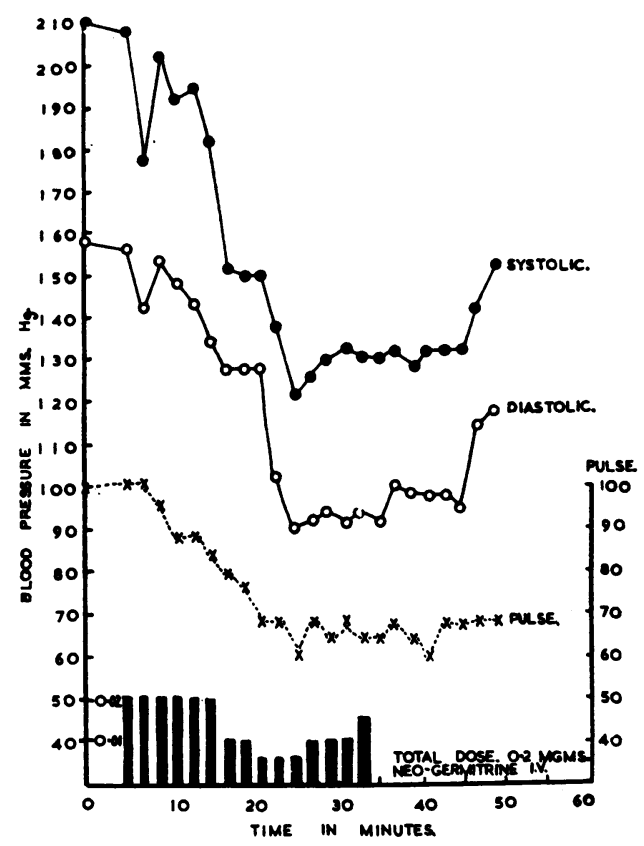

Fig. 2.-Example of slowly progressive fall of blood pressure and pulse rate as the dose of neogermitrine is gradually increased.

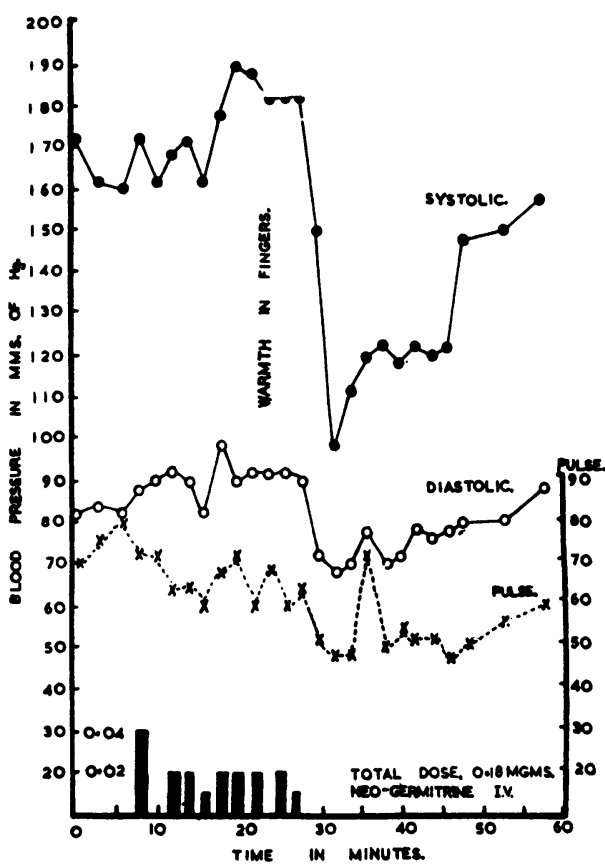

Fig. 3.-Example of abrupt fall of blood pressure beginning at a critical dose in the course of slow injection of neogermitrine.

addition of only $0.005 \mathrm{mg}$. (Fig. 3) shows how important it is to approach effective dosage circumspectly from below.

In 17 out of the 21 patients the minimal blood pressure levels in the recumbent position after neogermitrine lay between $132 / 80$ and $90 / 60$, the average blood pressure fall during the test being 116/58. In the remaining 4 patients the injection had to be stopped because of the onset of toxic or premonitory toxic manifestations and consequently the blood pressures did not fall so low, the minimum levels lying between $192 / 100$ and $152 / 108$, the average fall being $85 / 50$. The pulse rate usually fell to below 60 .

In all, toxic or premonitory toxic manifestations (for detail see later) occurred in 6 patients and were transient, discomfort lasting for about 10 minutes. By contrast, the fall in blood pressure might last one hour or more (Fig. 4). On occasion the blood pressure continued to fall after injection ceased. A considerable additional fall in blood pressure occurred in the erect posture without the development of toxic effects (Fig. 4).

(B) Subcutaneous Neogermitrine. As trial doses of intravenous neogermitrine induce effective falls in blood pressure with but little toxic effect, it was decided to explore the therapeutic possibilities of subcutaneous injections. Intramuscular and subcutaneous injections of veratrum alkaloids are most painful unless a local anæsthetic is added. A preparation of 0.05 per cent neogermitrine and 1 per cent procaine may be given subcutaneously, though local pain is not always avoided. 


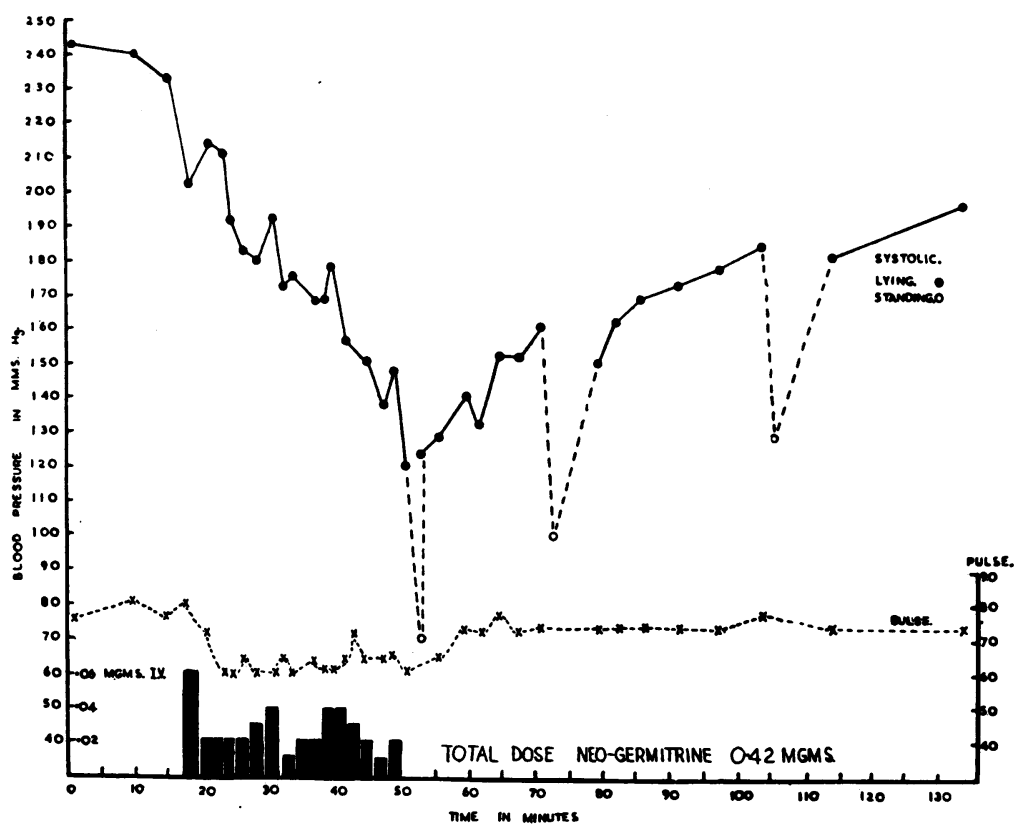

Fig. 4.-Prolonged blood pressure fall persisting after intravenous neogermitrine, with demonstration of postural hypotension.

Seven patients who had been unable to tolerate veratrum given by mouth were treated by subcutaneous injections of neogermitrine. Doses which led to an effective fall in blood pressure caused vomiting in 2 out of 7 patients. The 5 patients who appeared to tolerate effective doses of neogermitrine given subcutaneously, were given a period of trial therapy using this route of administration. The results were disappointing, as 3 out of the 5 developed toxic symptoms and treatment could not be continued. It is concluded that the subcutaneous injection of neogermitrine is not likely to provide effective treatment over long periods in many of the patients whose blood pressure levels cannot be controlled by oral administration.

(C) Intravenous Protoveratrine. Six patients were given protoveratrine intravenously, either in a single dose or fractionally administered as with neogermitrine. The effective intravenous dose was from $0.19 \mathrm{mg}$. to $0.30 \mathrm{mg}$.

The blood pressure falls more slowly after protoveratrine than after neogermitrine. The onset of the fall is ordinarily 10 minutes after injection and the maximum fall 15 minutes after. As with neogermitrine, effective doses usually cause bradycardia. The fall in blood pressure was 60/34, $106 / 72,108 / 74,154 / 74,100 / 62,120 / 70$, from levels of $214 / 128,204 / 138,186 / 128,232 / 132,198 / 126$, $230 / 130$ respectively. Nausea occurred in one test.

(D) Subcutaneous Protoveratrine. Five of the patients who had already received neogermitrine were given subcutaneous injections of protoveratrine (with 1 per cent procaine). The results were similar to those obtained by subcutaneous injection of neogermitrine, toxic effects appearing in the same patients. It is clear that in acute experiments protoveratrine is better tolerated parenterally than by oral administration in the sense that there are larger blood pressure falls with less general toxicity.

It has not yet been decided whether continued subcutaneous injections of protoveratrine are feasible in a large proportion of patients, but the impression was gained that the margin between therapeutic and toxic effects narrowed with continued administration. 
TABLE I

Effects on Blood Pressure and Pulse Rate of Neogermitrine Administered INTRAVENOUSLY

\begin{tabular}{|c|c|c|c|c|c|c|c|c|}
\hline \multirow{2}{*}{$\begin{array}{l}\text { Case } \\
\text { No. }\end{array}$} & \multicolumn{2}{|c|}{$\begin{array}{c}\text { Before } \\
\text { administration }\end{array}$} & \multirow{2}{*}{ Dose } & \multicolumn{2}{|c|}{$\begin{array}{c}\text { After } \\
\text { administration }\end{array}$} & \multirow{2}{*}{$\begin{array}{c}\text { Blood } \\
\text { pressure } \\
\text { fall }\end{array}$} & \multirow{2}{*}{$\begin{array}{c}\text { Duration } \\
\text { of blood } \\
\text { pressure } \\
\text { fall } \\
\text { (min.) }\end{array}$} & \multirow{2}{*}{$\begin{array}{l}\text { Toxic } \\
\text { effects }\end{array}$} \\
\hline & $\begin{array}{c}\text { Blood } \\
\text { pressure } \\
(\mathrm{mm} . \mathrm{Hg})\end{array}$ & $\begin{array}{l}\text { Pulse } \\
\text { rate }\end{array}$ & & $\begin{array}{c}\text { Blood } \\
\text { pressure } \\
(\mathrm{mm} . \mathrm{Hg})\end{array}$ & $\begin{array}{l}\text { Pulse } \\
\text { rate }\end{array}$ & & & \\
\hline $\begin{array}{r}98 \\
169 \\
207 \\
203 \\
167 \\
165\end{array}$ & $\begin{array}{l}194 / 142 \\
210 / 158 \\
244 / 170 \\
242 / 164 \\
220 / 164 \\
188 / 112\end{array}$ & $\begin{array}{r}84 \\
100 \\
80 \\
96 \\
88 \\
94\end{array}$ & $\begin{array}{l}0.125 \mathrm{mg} .(15) \\
0.11 \mathrm{mg} .(10) \\
0.17 \mathrm{mg} .(15) \\
0.195 \mathrm{mg} .(20) \\
0.15 \mathrm{mg} .(24) \\
0.16 \mathrm{mg} .(18)\end{array}$ & $\begin{array}{r}100 / 82 \\
122 / 90 \\
152 / 98 \\
90 / 60 \\
116 / 76 \\
102 / 62\end{array}$ & $\begin{array}{l}48 \\
60 \\
48 \\
64 \\
44 \\
40\end{array}$ & $\begin{array}{c}94 / 60 \\
88 / 68 \\
92 / 72 \\
152 / 104 \\
104 / 88 \\
86 / 50\end{array}$ & $\begin{array}{l}30 \\
40 \\
60 \\
45 \\
60 \\
60\end{array}$ & $\begin{array}{l}\text { Nil } \\
\text { Nil } \\
\text { Vomiting } \\
\text { Nil } \\
\text { Nil } \\
\text { Nausea } \\
\text { Hiccough }\end{array}$ \\
\hline $\begin{array}{r}137 \\
40 \\
263 \\
77 \\
171 \\
82 \\
152 \\
110 \\
183 \\
268 \\
162 \\
258 \\
204 \\
100 \\
1 Y\end{array}$ & $\begin{array}{c}284 / 144 \\
230 / 140 \\
210 / 130 \\
190 / 98 \\
240 / 138 \\
200 / 110 \\
238 / 122 \\
300+/ 178 \\
208 / 108 \\
248 / 102 \\
242 / 110 \\
256 / 122 \\
244 / 170 \\
248 / 148 \\
200 / 108\end{array}$ & $\begin{array}{r}88 \\
88 \\
88 \\
80 \\
88 \\
92 \\
88 \\
108 \\
76 \\
96 \\
80 \\
86 \\
80 \\
84 \\
84\end{array}$ & $\begin{array}{l}0.165 \mathrm{mg} .(22) \\
0.09 \mathrm{mg} .(14) \\
0 \cdot 11 \mathrm{mg} .(8) \\
0.20 \mathrm{mg} .(22) \\
0.12 \mathrm{mg} .(10) \\
0.17 \mathrm{mg} .(27) \\
0.15 \mathrm{mg} .(15) \\
0.15 \mathrm{mg} .(20) \\
0.145 \mathrm{mg} .(22) \\
0.21 \mathrm{mg} .(20) \\
0.42 \mathrm{mg} .(30) \\
0.32 \mathrm{mg} .(33) \\
0.27 \mathrm{mg} .(22) \\
0.17 \mathrm{mg} .(13) \\
0.17 \mathrm{mg} .(14)\end{array}$ & $\begin{array}{c}116 / 78 \\
92 / 70 \\
100 / 76 \\
98 / 68 \\
104 / 80 \\
104 / 70 \\
132 / 80 \\
192 / 100 \\
112 / 70 \\
122 / 68 \\
120 / 82 \\
176 / 92 \\
182 / 108 \\
102 / 78 \\
98 / 60\end{array}$ & $\begin{array}{l}40 \\
60 \\
52 \\
48 \\
40 \\
64 \\
50 \\
62 \\
50 \\
70 \\
60 \\
60 \\
56 \\
48 \\
44\end{array}$ & $\begin{array}{r}168 / 66 \\
138 / 70 \\
110 / 54 \\
92 / 30 \\
136 / 58 \\
96 / 40 \\
106 / 42 \\
108 / 78 \\
96 / 38 \\
126 / 34 \\
122 / 28 \\
80 / 30 \\
62 / 62 \\
146 / 70 \\
102 / 48\end{array}$ & $\begin{array}{r}60 \\
10 \\
25 \\
70 \\
30 \\
80 \\
25 \\
10 \\
80 \\
35 \\
60 \\
10 \\
5 \\
50 \\
90\end{array}$ & $\begin{array}{l}\text { Nausea } \\
\text { Nil } \\
\text { Nil } \\
\text { Nil } \\
\text { Nil } \\
\text { Nil } \\
\text { Nil } \\
\text { Nausea } \\
\text { Nil } \\
\text { Nil } \\
\text { Nil } \\
\text { Salivation } \\
\text { Vomiting } \\
\text { Nil } \\
\text { Nausea }\end{array}$ \\
\hline
\end{tabular}

Figs. in brackets mean minutes.

\section{Oral Administration of Pure Veratrum Alkaloids}

The response of 39 patients to oral neogermitrine or protoveratrine were studied and compared with their responses to various mixed veratrum alkaloid preparations. Twelve patients received trials both with neogermitrine and with protoveratrine, an additional 22 had neogermitrine alone, and an additional 5 protoveratrine alone.

(A) Neogermitrine. Thirty-four patients had trials with oral neogermitrine. The lowest oral dose of neogermitrine that produced a useful fall of blood pressure was $0.4 \mathrm{mg}$., and the largest single dose given was $1.4 \mathrm{mg}$. The usual single effective dose was between $0.5 \mathrm{mg}$. and $0.8 \mathrm{mg}$.

In most patients doses of $0.1 \mathrm{mg}$. below the optimum dose caused no significant fall of blood pressure, and doses of $0.1 \mathrm{mg}$. too great led to marked toxic symptoms and profound hypotension. In 16 out of the 34 patients there was no difference between the toxic and effective doses, and toxic manifestations preceded or coincided with significant hypotensive effects. In 8 out of the 34 patients the margin between doses producing significant falls in blood pressure and doses producing toxicity was less than $0.1 \mathrm{mg}$., and in this group of patients the effect of oral administration was not constant enough to allow such a small difference to be of therapeutic value. Attempts to use divided dosage in these patients were not successful (Fig. 5).

In the remaining 10 patients, however, the difference between the therapeutic and the toxic dose was more than $0.1 \mathrm{mg}$., and in these patients reduction of blood pressure could be achieved in acute experiments without significant toxic manifestations. The doses of neogermitrine used on patients treated successfully were similar to those producing toxic effects in other patients, so that freedom from toxic effects was not always related to the size of the dose. 
(B) Protoveratrine. Seventeen patients were given protoveratrine by mouth. The doses of protoveratrine used ranged between $0.5 \mathrm{mg}$. and $2.0 \mathrm{mg}$. the usual effective dose being between 1.0 and $1.25 \mathrm{mg}$. Dosage was as critical for each patient as with neogermitrine.

In 5 out of the 17 patients the same dose caused hypotensive effects and toxic effects; in 6 of the 17 patients a small difference of $0.25 \mathrm{mg}$. occurred, while in the remaining 6 patients the thera-

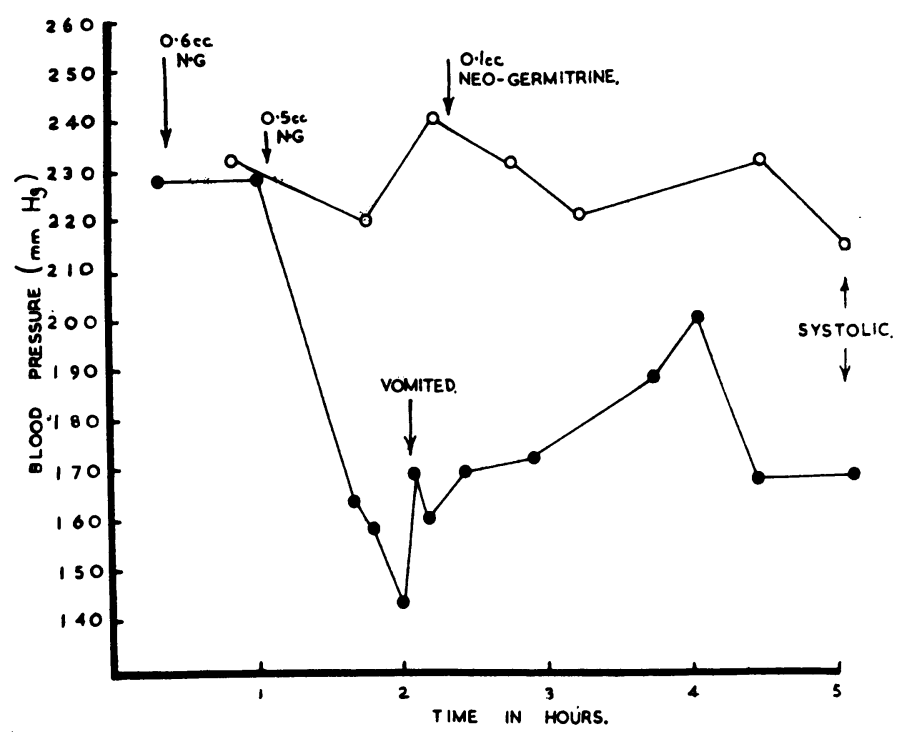

FIG. 5.-Attempt to avoid toxic effects from $0.6 \mathrm{mg}$. of neogermitrine by giving $0.5 \mathrm{mg}$. followed by $0.1 \mathrm{mg}$. one hour later led to diminution of hypotensive action.

peutic and toxic doses differed by more than $0 \cdot 25 \mathrm{mg}$. As with neogermitrine, the size of dose in successful and unsuccessful patients was similar.

Postural falls of blood pressure was not severe after oral administration except following toxic symptoms. In patients taking the drugs regularly little difference in blood pressure in varying postures was observed.

\section{Comparison of Effects of Pure and Mixed Alkaloids}

Most of the 39 patients who have received trial doses of the two pure alkaloids have also been given trial doses of various mixed alkaloidal preparations. In addition, we have compared the results of the trials with mixed alkaloids that were reported by Smirk and Chapman (1952) with the effects of the pure alkaloids in this series.

There appears to be no important difference between the effects of neogermitrine or protoveratrine and the mixed alkaloid preparations when administered orally. Neogermitrine appears to be the most powerful preparation, being about $1 \frac{1}{4}$ times as effective as protoveratrine. The mixed alkaloids are considerably less active, exhibiting about one-fifth to one-tenth the activity of neogermitrine on oral administration.

The pure alkaloids act more rapidly, having their maximum effect in from 1 to $1 \frac{1}{2}$ hours, as compared with the $2-3$ hours for the mixed alkaloids. Thus in Case 152 the maximum blood pressure fall both with neogermitrine and protoveratrine was at $1 \frac{1}{4}$ hours, while the mixed alkaloids had their maximum action $2 \frac{1}{2}$ hours after administration.

Toxic effects of neogermitrine and protoveratrine did not differ significantly from those of anatensol, vertavis, or the amorphous mixed alkaloids. They consist of such symptoms as a burning sensation in the mouth, followed by a retrosternal choking sensation, hiccough, salivation, 
TABLE II

Effect on Blood Pressure of Oral administration of Neogermitrine

\begin{tabular}{|c|c|c|c|c|c|}
\hline $\begin{array}{l}\text { Case } \\
\text { No. }\end{array}$ & $\begin{array}{c}\text { Maximal } \\
\text { subtoxic dose } \\
\text { (neogermitrine) } \\
\text { (mg.) }\end{array}$ & $\begin{array}{c}\text { Blood } \\
\text { pressure } \\
\text { fall }\end{array}$ & $\begin{array}{l}\text { Toxic dose } \\
\text { (mg.) }\end{array}$ & $\begin{array}{c}\text { Blood } \\
\text { pressure } \\
\text { fall }\end{array}$ & $\begin{array}{l}\text { Result } \\
\text { of test }\end{array}$ \\
\hline $\begin{array}{r}191 \\
61 \\
258 \\
203 \\
162 \\
202 \\
161 \\
103 \\
268 \\
221 \\
40 \\
171 \\
165 \\
137 \\
261 \\
172 \\
152 \\
182 \\
193 \\
16 \\
204 \\
178 \\
321 \\
223 \\
167 \\
206 \\
194 \\
183 \\
298 \\
300 \\
305 \\
318 \\
320 \\
325\end{array}$ & $\begin{array}{l}0.85 \\
0.5 \\
0.7 \\
0.75 \\
1.0 \\
0.55 \\
0.55 \\
0.7 \\
0.6 \\
0.4 \\
0.5 \\
0.6 \\
0.8 \\
0.5 \\
0.5 \\
0.6 \\
0.8 \\
0.6 \\
0.9 \\
0.9 \\
1.3 \\
0.95 \\
0.6 \\
0.55 \\
0.7 \\
0.8 \\
0.9 \\
0.6 \\
0.9 \\
0.5 \\
0.9 \\
0.6 \\
0.6 \\
0.5\end{array}$ & $\begin{array}{c}10 / 6 \\
32 / 12 \\
52 / 44 \\
90 / 20 \\
84 / 46 \\
56 / 32 \\
0 / 0 \\
40 / 28 \\
42 / 16 \\
21 / 12 \\
16 / 6 \\
18 / 6 \\
74 / 32 \\
26 / 8 \\
32 / 12 \\
36 / 20 \\
64 / 48 \\
38 / 22 \\
0 / 0 \\
28 / 16 \\
84 / 44 \\
30 / 10 \\
18 / 6 \\
22 / 24 \\
64 / 42 \\
18 / 10 \\
56 / 48 \\
32 / 14 \\
28 / 18 \\
42 / 32 \\
28 / 18 \\
20 / 12 \\
8 / 2 \\
46 / 21\end{array}$ & $\begin{array}{c}0.9 \\
0.55 \\
0.8 \\
0.75 \\
1.1 \\
\text { Not reached } \\
0.6 \\
0.8 \\
0.65 \\
0.5 \\
0.6 \\
0.7 \\
\text { Not reached } \\
0.6 \\
0.6 \\
0.7 \\
\text { Not reached } \\
0.7 \\
1.0 \\
0.95 \\
1.4 \\
1.0 \\
0.7 \\
0.6 \\
\text { Not reached } \\
0.85 \\
1.0 \\
0.7 \\
1.0 \\
0.6 \\
1.0 \\
0.7 \\
0.7 \\
\text { Not reached }\end{array}$ & $\begin{array}{c}73 / 34 \\
48 / 16 \\
74 / 32 \\
100 / 46 \\
130 / 56 \\
= \\
20 / 5 \\
82 / 68 \\
84 / 66 \\
44 / 32 \\
78 / 44 \\
84 / 36 \\
64 / 28 \\
52 / 34 \\
68 / 46 \\
84 / 44 \\
40 / 32 \\
16 / 8 \\
86 / 44 \\
60 / 22 \\
60 / 14 \\
132 / 54 \\
72 / 30 \\
148 / 64 \\
86 / 64 \\
20 / 6 \\
80 / 52 \\
128 / 82 \\
82 / 40 \\
70 / 24 \\
-\end{array}$ & $\begin{array}{l}\text { Failed } \\
\text { Failed } \\
\text { Success } \\
\text { Failed } \\
\text { Success } \\
\text { Success } \\
\text { Failed } \\
\text { Failed } \\
\text { Failed } \\
\text { Failed } \\
\text { Failed } \\
\text { Failed } \\
\text { Success } \\
\text { Failed } \\
\text { Failed } \\
\text { Failed } \\
\text { Success } \\
\text { Failed } \\
\text { Failed } \\
\text { Failed } \\
\text { Success } \\
\text { Failed } \\
\text { Failed } \\
\text { Failed } \\
\text { Success } \\
\text { Failed } \\
\text { Failed } \\
\text { Failed } \\
\text { Failed } \\
\text { Success } \\
\text { Failed } \\
\text { Failed } \\
\text { Failed } \\
\text { Success }\end{array}$ \\
\hline
\end{tabular}

nausea, and vomiting. Toxic manifestations were usually accompanied by a considerable fall in arterial pressure, frequently to systolic levels below $100 \mathrm{~mm}$. $\mathrm{Hg}$. In many cases no hypotensive effect was observed until toxic manifestations occurred. A precipitous fall in arterial pressure then followed, with faintness and hypotension when standing up. Faintness was rapidly overcome by lying down. Vomiting was frequently caused by food; a mid-morning cup of tea or occasionally lunch being followed by nausea and sometimes vomiting within a few minutes.

The effective oral dose of either neogermitrine, protoveratrine, or the mixed alkaloids was smaller if taken before food than if taken after a meal; doses that produced little effect when taken after a meal produced hypotension and sometimes toxic effects if taken fasting. We have found that if small doses are given before meals the effects of a given dose are more constant from day to day than are the effects of the larger doses required after food. This would appear to be due to more rapid and complete absorption when taken fasting.

In only one patient did any discrepancy appear between the effects of neogermitrine and those of protoveratrine or mixed veratrum alkaloids. In this patient (Case 202) no toxic manifestations occurred with neogermitrine, although with other preparations there was no difference between toxic and therapeutic doses. Control of the blood pressure in this patient proved to be transient. 


\section{The Basal Blood Pressure as a Means of Predicting the Response to Veratrum}

The relationship between basal blood pressure and results of treatment is summarized in Table IV. Reviewing the 65 patients who have taken one or more veratrum preparations, we noted that those with basal diastolic pressures of $100 \mathrm{~mm}$. $\mathrm{Hg}$ or less have responded better than those

TABLE III

Effect on Blood Pressure of Oral Administration of Protoveratrine

\begin{tabular}{|c|c|c|c|c|c|}
\hline $\begin{array}{l}\text { Case } \\
\text { No. }\end{array}$ & $\begin{array}{c}\text { Maximal } \\
\text { subtoxic dose } \\
\text { (protoveratrine) } \\
\text { (mg.) }\end{array}$ & $\begin{array}{l}\text { Blood } \\
\text { pressure } \\
\text { fall }\end{array}$ & $\begin{array}{l}\text { Toxic dose } \\
\text { (mg.) }\end{array}$ & $\begin{array}{l}\text { Blood } \\
\text { pressure } \\
\text { fall }\end{array}$ & $\begin{array}{l}\text { Result } \\
\text { of test }\end{array}$ \\
\hline $\begin{array}{r}191 \\
203 \\
33 \\
169 \\
162 \\
157 \\
16 \\
61 \\
204 \\
221 \\
178 \\
193 \\
202 \\
161 \\
207 \\
159 \\
152\end{array}$ & $\begin{array}{l}1.0 \\
0.5 \\
1.0 \\
1.0 \\
1.25 \\
1.0 \\
1.25 \\
0.5 \\
1.75 \\
0.625 \\
1.0 \\
0.5 \\
0.75 \\
1.0 \\
1.25 \\
1.5 \\
1.25\end{array}$ & $\begin{array}{c}0 / 0 \\
0 / 0 \\
30 / 20 \\
70 / 22 \\
80 / 56 \\
64 / 30 \\
30 / 14 \\
0 / 0 \\
72 / 44 \\
34 / 22 \\
30 / 14 \\
0 / 0 \\
38 / 12 \\
30 / 18 \\
0 / 0 \\
130 / 62 \\
76 / 39\end{array}$ & $\begin{array}{c}1.25 \\
0.75 \\
1.25 \\
\text { Not reached } \\
\text { Not reached } \\
\text { Not reached } \\
1.5 \\
0.625 \\
\text { Not reached } \\
0.75 \\
1.25 \\
0.75 \\
0.875 \\
1.25 \\
1.5 \\
2.0 \\
\text { Not reached }\end{array}$ & $\begin{array}{c}54 / 38 \\
70 / 40 \\
138 / 100 \\
- \\
- \\
64 / 38 \\
68 / 60 \\
- \\
42 / 38 \\
60 / 24 \\
72 / 60 \\
50 / 36 \\
50 / 38 \\
98 / 56 \\
150 / 70 \\
-\end{array}$ & $\begin{array}{l}\text { Failed } \\
\text { Failed } \\
\text { Failed } \\
\text { Success } \\
\text { Success } \\
\text { Success } \\
\text { Failed } \\
\text { Failed } \\
\text { Success } \\
\text { Failed } \\
\text { Failed } \\
\text { Failed } \\
\text { Failed } \\
\text { Failed } \\
\text { Failed } \\
\text { Success } \\
\text { Success }\end{array}$ \\
\hline
\end{tabular}

with higher basal diastolic pressures. Of the 19 patients with basal diastolic pressures of 100 or below, 13 could be successfully treated. By contrast, none of the 32 patients with basal diastolic pressures above 120 could be successfully controlled for any length of time with veratrum alkaloids.

TABLE IV

Relationship Between the Basal Diastolic Blood Pressure and Control AChieved by Veratrum Alkaloids

\begin{tabular}{|c|c|c|c|c|c|}
\hline \multicolumn{3}{|c|}{$\begin{array}{c}\text { Basal } \\
\text { diastolic pressure }\end{array}$} & Successes & Failures & Total \\
\hline $\begin{array}{l}\text { Below } 100 \\
100-120 \\
\text { Above } 120\end{array}$ & $\begin{array}{l}\ldots \\
\cdots \\
\cdots\end{array}$ & $\begin{array}{l}\ldots \\
\cdots \\
\cdots\end{array}$ & $\begin{array}{r}13 \\
8 \\
0\end{array}$ & $\begin{array}{r}6 \\
6 \\
32\end{array}$ & $\begin{array}{l}19 \\
14 \\
32\end{array}$ \\
\hline \multicolumn{2}{|c|}{ Total number of cases } & $\ldots$ & 21 & 44 & 65 \\
\hline
\end{tabular}

The Effects of Acute and Continued Administration

Trials of various oral doses indicate clearly those patients in whom a good fall in blood pressure cannot be produced without preceding or accompanying toxic manifestations. These patients form the majority of the present series. Attempts at continued treatment were made in all of the 21 patients who had a symptomless fall in blood pressure. It has been found, however, that toxic manifestations become more frequent after administration has been continued for periods of a month or more. The apparent narrowing of the margin between therapeutic and toxic effects appears to 
occur to some degree in all patients with continued administration. In 11 of the 21 patients originally thought to be suitable for oral therapy, toxic manifestations became so frequent that treatment could not be continued.

\section{Discussion}

It has been shown that a very large fall in blood pressure can be produced by the intravenous administration of the pure veratrum alkaloids neogermitrine and protoveratrine, toxic effects occurring in about one-third of patients. A similar fall in blood pressure may be obtained by subcutaneous or oral administration of these alkaloids, but toxic effects occur in over two-thirds of patients. It would appear probable that the lower incidence of toxic effects when the intravenous route is used is due to the extremely accurate small doses; it seems that the margin between therapeutic and toxic effects is too narrow in most patients to enable successful subcutaneous or oral therapy to be used. Hence an intravenous test is not a guide to the value of prolonged subcutaneous or oral therapy.

Comparison between the effects of the pure alkaloids neogermitrine and protoveratrine on the one hand, and the mixed alkaloidal preparations on the other, indicates that the pure alkaloids cause toxic side effects almost as frequently as the less purified preparations. Hence it appears likely that the toxic effects of the mixed alkaloidal preparations are not due to the presence of contaminating constituents, but are caused mainly by the alkaloids themselves.

The level of the basal diastolic pressure seems to afford some indication of the chance of obtaining a good fall in blood pressure without toxicity, since about two-thirds of patients with low basal diastolic pressures could be effectively treated. Freis and Stanton (1948) gained the impression that patients with high diastolic pressures responded as well as the early mild cases. The difference between their results and ours might be due to the fact that we have aimed at greater reduction in blood pressure.

Tests undertaken with inert control substances have demonstrated that considerable falls in blood pressures may occur spontaneously, especially in patients with low basal blood pressures. Hence, great care must be taken in the interpretation of the blood pressure falls obtained following the administration of any hypotensive drug which is being tested. We are confident, however, that the falls in blood pressure that have been observed in patients with labile hypertension following the administration of the veratrum alkaloids are greater and more consistent than those obtained by the administration of a placebo.

\section{SUMmary}

Minute doses such as $0.1 \mathrm{mg}$. of neogermitrine or $0.15 \mathrm{mg}$. of protoveratrine, when given intravenously in hypertensive patients, produce falls of blood pressure to normal or even to hypotensive levels. Rather larger doses $(0.4 \mathrm{mg}$.) given subcutaneously or orally have similar effects.

The therapeutic margin between toxic and hypotensive doses is not distinctly greater with the pure alkaloids than with mixed alkaloidal preparations. The alkaloids that lower the blood pressure also lead to the characteristic toxic manifestations.

The blood pressure may be reduced more readily without toxic symptoms in labile than in fixed hypertension.

Toxic effects have been less frequent when the veratrum alkaloids have been given in small subdivided doses intravenously than when administered by mouth or subcutaneously. An explanation is discussed.

Of 65 hypertensive patients in whom veratrum treatment has been attempted here, a good measure of control over the level of the blood pressure has been possible in about 15 . Although a good control over the blood pressure can be obtained for a time in a larger number of patients, the margin between therapeutic and toxic doses narrows and effective treatment cannot be maintained in all patients who began well. 
We are indebted to Mr. W. G. H. Edwards of the Chemistry Department, University of Otago, for the isolation of neogermitrine; to Dr. O. W. Chapman, Assistant Physician, Dunedin Hospital, for permission to quote some of the cases reported in an earlier publication; to Miss J. Rivers for technical assistance; and to Miss M. Popplewell for secretarial assistance.

The following firms have given generous supplies of materials:-anatensol from Messrs. E. R. Squibb \& Sons, New York, N.Y.; vertavis from Messrs. Irwin, Neisler \& Co., Decatur, Ill.; protoveratrine from Riker Laboratories, Inc., Los Angeles and Messrs. Eli Lilly \& Co., Indianapolis, Ind.

This research was supported in part by the Medical Research Council of New Zealand.

\section{REFERENCES}

Aviado, D. M., Jr., and Pontius, R. G. (1949). Fed. Proc., 8, 5.

Baker, P. de L. (1860). London Lancet (New York) 1, 362.

Barrow, J. G., and Sikes, C. R. (1951). Amer. Heart J., 41, 742.

Coe, W. S., Best, M. M., and Kinsman, J. M. (1950). J. Amer. med. Ass., 143, 5.

Committee for the Standardization of Blood Pressure Readings of the American Heart Association and of the Cardiac Society of Great Britain and Ireland (1939). J. Amer. med. Ass., 113, 294.

Cramer, W. (1915). J. pharmacol exper. Therap., 7, 63.

Doyle, A. E., and Smirk, F. H. (1952). Proc. Univ. Otago med. Sch., 30, 5.

Faust, F. B. (1951). Lancet, 71, 65.

Freis, E. D., and Stanton, J. R. (1948). Amer. Heart J., 36, 723. 28, 353.

- and Moister, F. C. (1950). J. Pharmacol. exper. Therap., 98, 166.

Fried, J., White, H. L., and Wintersteiner, O. (1949). J. Amer. chem. Soc., 71, 3260.

$\overline{\text { Hite, W. K. (1946). Illinois med. J., } 90,336 .}$

Kauntze, R., and Trounce, J. (1951). Lancet, 1, 549.

Kilpatrick, J. A. (1948). Brit. Heart J., 10, 48.

Krayer, O., and Acheson, G. A. (1946). Physiol. Rev., 26, 383.

, Moe, G. K., and Mendez., R. (1944). J. Pharmacol. exper. Therap., 82, 167.

Meilman, E., and Krayer, O. (1950). Circulation, 1, 204.

McNair, J. D., Griffith, G. C., and Elek, S. R. (1950). Amer. Heart J., 40, 382.

Prevost, J. L. (1866). Compt. rend soc. biol., 18, 133.

Smirk, F. H. (1944). Brit. Heart J., 6, 176.

—, and Alstad, K. S. (1951). Brit. med. J., 1, 1217.

-, and Chapman, O. W. (1952). Amer. Heart J., 43, 586.

von Bezold, A., and Hirt, L. (1867). Untersuch. physiol. Lab., Würzburg, pt. 1, 73. 